Z. Klin. Chem. Klin. Biochem.

10. Jg. 1972 , S. $502-508$

\title{
A Simple Assay for Specific Estrogen Binding Capacity in Human Mammary Tumours.
}

\author{
By C. B. Korsten and J.-P. Persijn \\ From the Department of Clinical Chemistry (Head: Dr.J.-P. Persijn), Netberlands Cancer Institute, Amsterdam
}

(Eingegangen am 3. Juli 1972)

\begin{abstract}
A simple method is described for the measurement of specific binding of estradiol by extracts of human mammary tumours or metastases. The method, which is applicable to small samples, involves incubation of homogenate with labelled estradiol. As a control, specific binding is abolished by preheating at $45-50^{\circ} \mathrm{C}$, or the addition of a potent anti-estrogen (U 11, 100).

Free and bound estradiol are separated by charcoal.

Of 59 biopsies histologically verified as malignant, 41 were found to contain estradiol binding receptor.
\end{abstract}

Eine einfache Methode zur Bestimmung der spezifischen Bindung von Östradiọl durch Extrakte von menschlichen Mammatumoren oder deren Metastasen wird beschrieben.

Die Methode ist für kleine Proben anwendbar. Das Homogenat wird mit radioaktiv markiertem Östradiol inkubiert. Als Kontrolle wird auf $45-50^{\circ} \mathrm{C}$ erhitztes Homogenat verwendet oder Homogenat nach Zugabe eines hochwirksamen Anti-Östrogens (U.11. 100), das die spezifische Bindung aufhebt.

Freies und gebundenes Östradiol werden mit Aktivkohle getrennt.

Von 59 histologisch als maligne gesicherten Biopsieproben wurde bei 41 der Östradiol-bindende Rezeptor nachgewiesen.

It is now generally accepted, particularly through the work of JENSEN et al $(1,2)$, that in the uptake of estrogens by cells of target organs, the hormone is bound specifically to a cytoplasmic protein, which is called "receptor".

The binding of estrogen to its receptor appears to be an early but essential step in the mechanism of stimulation of biosynthetic processes in cells of hormone-dependent tissues. Several investigators $(3,4,5)$ have observed that some, but not all, human malignant breast tumours can accumulate estrogens in vivo.

These findings are interesting in view of the clinical observation that only some patients benefit from hormonal therapy.

A link between the hormone dependency of breast tumours and their ability to accumulate estrogens has been noticed by Folca et al (3). These workers injected tritium labelled estrogens into ten patients with breast cancer shortly before they were submitted to adrenalectomy. Biopsies of tumour tissue were taken and assayed for their tritium activity. In four patients the concentration of tritium was higher then in muscle and only these patients were benefiting from the therapy.

In later studies JENSEN et al (16) found evidence that certain human breast tumours contain receptor proteins.

If the presence of estrogen receptors determines the hormone dependency of breast tumours, their assay might be of major importance in the choice of treatment. The data gathered thus far $(3,6,7)$ suggest that a routine assay of the specific estrogen binding capacity (by receptor) of tumours might provide a clinically valuable parameter.
The assay of the estradiol binding receptor of the tumour should be done in vitro rather than by in vivo studies (8).

TERENIUS (7) incubated tissue slices in buffer containing labelled estradiol. As a control, slices from the same tumour were incubated in an identical medium to which Upjohn 11, 100 had been added.

Upjohn 11, 100 is a potent anti-estrogen, which suppresses specifically the binding of estrogens to receptor proteins from rat target organs (2). The extent to which the accumulation of radioactivity was suppressed by Upjohn 11, 100 was considered to represent receptor bound estradiol. It was found by this technique that only some of the patients had tumours with estradiol binding capacity.

The present paper describes a simple technique which can handle a large number of samples. Tumours from a number of patients (71) were assayed for estrogen receptors in order to extend the available data.

\section{Materials and Methods \\ Hormones}

Tritium labelled estradiol-17 $\beta$ (labelled in the 6,7 positions) with a specific activity of $40 \mathrm{Ci} / \mathrm{mole}$ ) was purchased from the Radiochemical Centre Amersham, England. The unlabelled estradiol-17 $\beta$ was obtained from the Sigma Chemical Company, St. Louis, USA. Upjohn 11, 100 (1-[2-[p-(3.4-dihydro-6-methoxy-2-phenyl-1naphtyl) phenoxy]-ethyl]pyrrolidine $\mathrm{HCl}$ ) was a gift from the Upjohn Company, Brussels, Belgium.

\section{Tumours}

Tumour tissues (breast or biopsies from metastases in the skin) were freed from fat as completely as possible. The tissues were stored at $-90^{\circ} \mathrm{C}$. This treatment does not significantly change the binding capacity of the receptor for the estrogen (9). 
Tab. 1

Procedure for measurement of estrogen binding capacity (modified KORENMAN and DUKES technique)

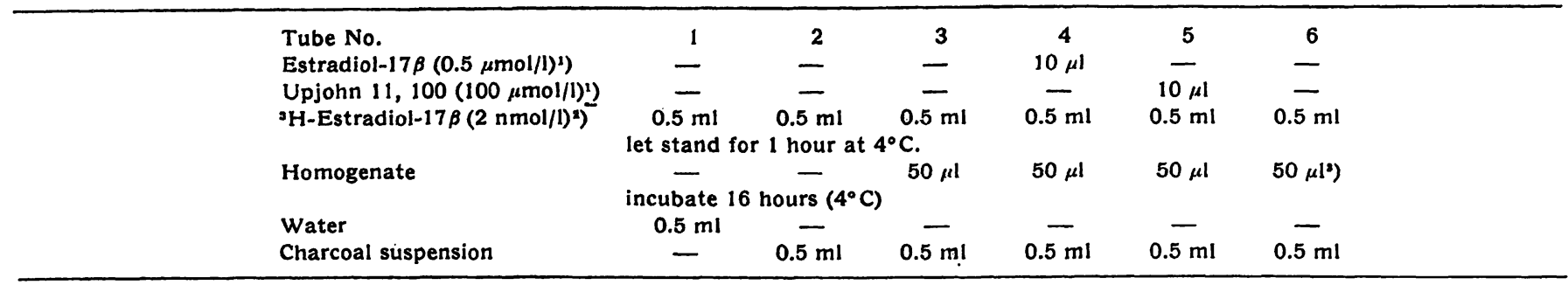

2) in ethanol

$\left.{ }^{2}\right)$ in $0.01 \mathrm{~mol} / 1$ Tris buffer $\mathrm{pH} 7.4$ containing $0.0015 \mathrm{~mol} / \mathrm{l}$ EDTA and $0.25 \mathrm{~mol} / \mathrm{l}$ sucrose

a) preheated at $45-50^{\circ} \mathrm{C}$ (1 hour)

\section{Procedures}

The assay of estrogen binding was carried out according to KORENMAN and DuKEs (10) with certain modifications: the homogenisation of the tissue was performed at low temperature as described by WAGNER $(11,12)$. Another modification was the use of additional controls for the measurement of unspecific binding. To control incubations containing labelled estradiol, Upjohn 11,100 was added for competitive inhibition. The measurement of the binding of labelled estradiol by homogenates which had been treated for 1 hour at $45-50^{\circ} \mathrm{C}$ served as a second control. WAGNER (10) found that preheating destroys the receptor protein binding capacity.

Several tumours were assayed for estrogen binding capacity using the electrophoresis technique of WAGNER $(11,12)$.

\section{Preparation of extract}

Tissue, still frozen, was pulverised in a porcelain mortar chilled in liquid nitrogen. Two or three volumes Tris buffer $(\mathrm{pH} 7.5$; $0.01 \mathrm{~mol} / \mathrm{l}$ ) were added to the mortar and the contents were pulverised again. The powder was left to thaw. The homogenate was centrifuged at $3000 \mathrm{rpm}$ for $20 \mathrm{~min}$ at $4^{\circ} \mathrm{C}$. The supernatant was filtered (Schleicher and Schüll 589/2).

Assay of binding capacity using the Korenman and Dukes tecbnique Table 1 summarizes the standard procedure. It should be noted that tubes 3, 4, 5 and 6 were treated in duplicate. Bound and free labelled estradiol were separated by centrifugation after the addition of dextran coated charcoal. Tubes 1 and 2 serve as a control for the removal of labelled estradiol by the charcoal suspension. The latter was prepared according to KorenMan and Dukes (10) Aliquots $(0.5 \mathrm{ml})$ of the supernatants were added to BRAY's fluid and counted in a liquid scintillation counter for the determination of tritium activity.

\section{Assay of binding capacity using electrophoresis}

The method of WAGNER separates estradiol bound to receptor from free and unspecifically bound estradiol by means of electrophoresis $(11,12)$. The homogenate was incubated with $2 \mathrm{nmol} / 1^{3} \mathrm{H}-$ estradiol-17 $\beta$ at $\mathrm{pH} 7.5$ (Tris buffer $0.01 \mathrm{~mol} / \mathrm{l}$ ) for two hours at $4^{\circ} \mathrm{C}$. After incubation the mixture was submitted to electrophoresis. Preheated ( 1 hour at $45^{\circ} \mathrm{C}$ ) homogenate was used as a control.

\section{Electrophoresis}

The electrophoresis has been described in detail elsewhere $(11,12)$. Briefly, a $5 \mathrm{~mm}$ thick layer of agar. on glass $(9 \times 9 \mathrm{~cm})$ was prepared from a $2 \%$ agar Noble solution in $0.05 \mathrm{~mol} / 1$ Veronal buffer. At the centre 10 holes were punched, the diameter of which was such that they could be filled with $50 \mu \mathrm{l}$ of the test solution. Two adjacent holes were filled with the same test solution. The glass plate supporting the agar layer rested on a block of copper brass the surface of which was maintained at $-10^{\circ} \mathrm{C}$. Thermoelectric measurements confirmed that the temperature in the agar did not rise above $+10^{\circ} \mathrm{C}$ during electrophoresis ( 2 hours, $80 \mathrm{~mA}$ ). After electrophoresis the agar layer was sliced in strips containing two holes each. The strips were cut into 15 pieces lengthways. The pieces were freeze-dryed and counted after burning in a Packard sample oxidizer.

\section{Results}

Figures $1-3$ show the electrophoretic patterns of homogenates of three different histologically verified human breast tumours. Two tumours show the presence of an

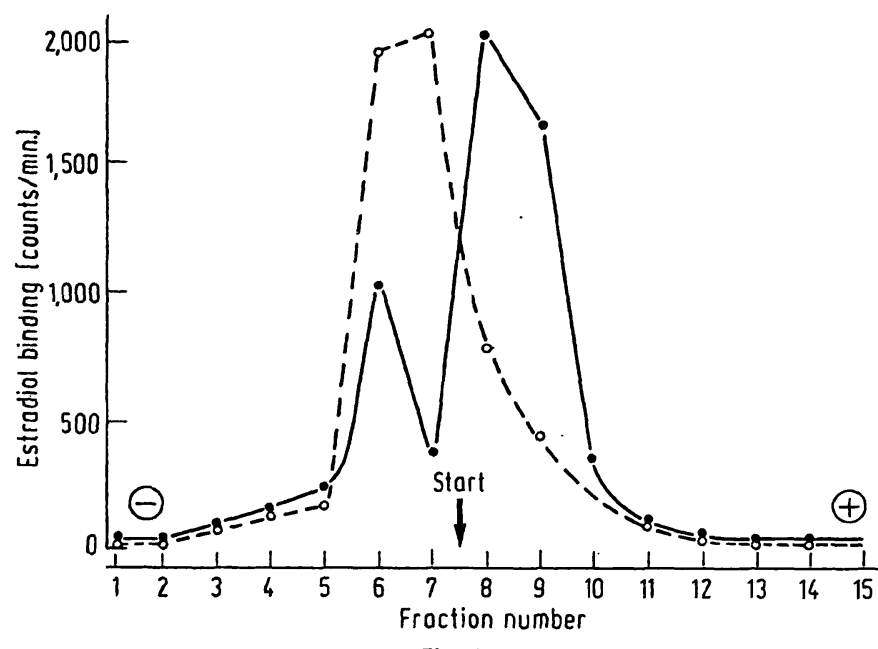

Fig. 1

Electrophoretic pattern of extract of tumour No. 1 after incubation with labelled ${ }^{3} \mathrm{H}$-estradiol. Endosmotic flow moves unbound ${ }^{3} \mathrm{H}$ estradiol and ${ }^{2} \mathrm{H}$-estradiol released from unspecifically binding protein to the cathode. The receptor bound estradiol appears in the anodic region. - - tumour homogenate, o-..- o tumour homogenate heated

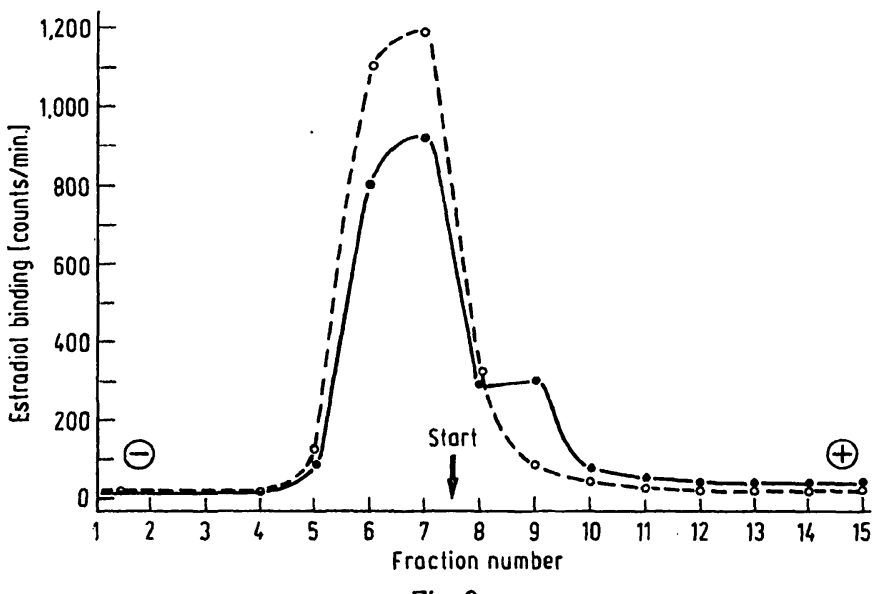

Fig. 2

Electrophoretic pattern of extract of tumour No. 2 after incubation with labelled "H-estradiol. - - . tumour homogenate, $0 . . .0$ tumour homogenate heated 


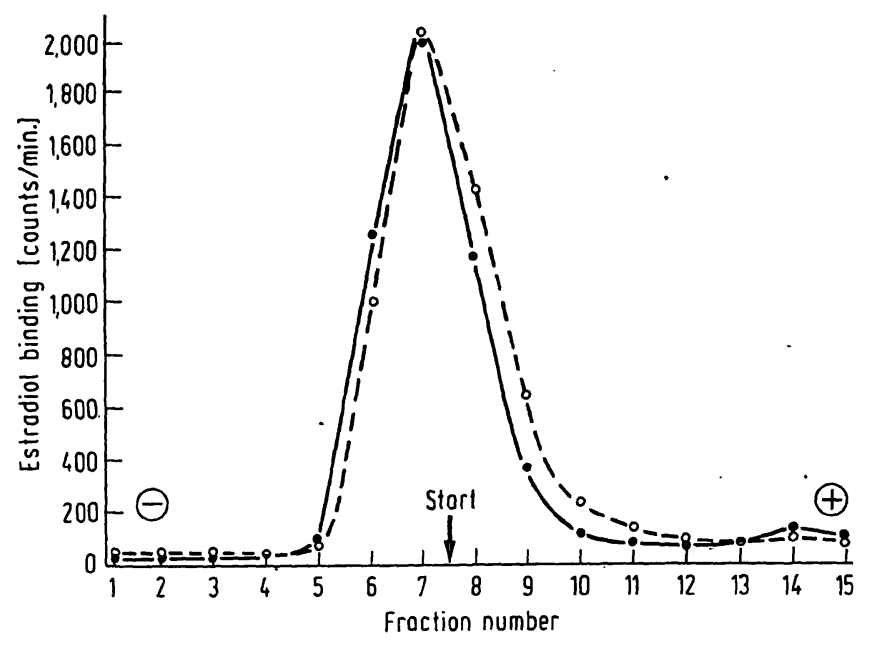

Fig. 3

Electrophoretic pattern of extract of tumour No. 3 after incubation with labelled ${ }^{3} \mathrm{H}$-estradiol. - - tumour homogenate, $0 .-.-0$ tumour homogenate heated

estradiol receptor in the anodic region. Figure 1 refers to a tumour possessing a high level and figure 2 to a tumour with a moderate level of estradiol receptor. Unbound excess of estradiol moves to the cathode.which permits separation of free and bound estradiol.

The albumin band is located before the receptor zone, but the weakly bound estradiol is released from albumin during the electrophoresis $(11,12)$.

Tumour 3 (fig. 3 ) shows only a large peak (unbound estradiol-17 $\beta$ ) which appears at the cathodic side. The curves for the preheated and unheated extracts coincide. This tumour is considered to be receptor negative.

The results of the modified Korenman and Dukes technique obtained with the tumours previously described are listed in table 2. Estradiol bindings are expressed as counting differences between the assay using labelled estradiol without any additive or pretreatment and the control experiments. Tumours 1 and 2 show strong and moderate binding, respectively. Since the counting difference using Upjohn 11, 100 is considered to give the most reliable measure for receptor bound estradiol-17 $\beta$, tumour No. 3 could be interpreted as receptor negative. It will be noted that the estradiol binding characteristics of tumours 1,2 and 3 are in agreement with those obtained by the electrophoresis technique. The latter, however, is not capable of handling a large number of samples within a short time. In addition the material available is limited, which

Tab. 2

Effect of unlabelled estradiol (excess), Upjohn 11, 100 or preheating on the binding of labelled estradiol by three tumour homogenates. These homogenates were also examined for their binding of labelled estradiol by agar gel electrophoresis (see fig. $1-3$ )

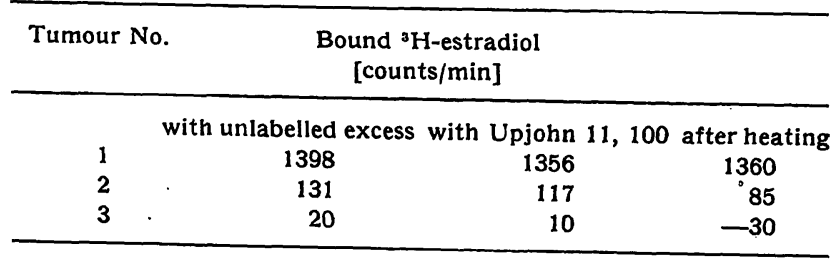

restricts both the number of tumours that can be investigated and the number of controls. The modified KORENMAN and DuKes technique was chosen as a routine method. The method is applicable to small $(100 \mathrm{mg}$ ) samples which is useful for the study of metastases.

The electrophoresis technique remains highly attractive for the study of fundamental problems e.g. binding studies with several 'estrogen antagonists etc. The quantitative aspects of the modified KORENMAN and DukEs technique were studied using dilution experiments. The results are depicted in figure 4. Table 3 shows counting differences between the assay using ${ }^{3} \mathrm{H}$-estradiol- $17 \beta$ alone and the controls as obtained for biopsies from human primary breast tumours or metastases. Comparison of the amounts of radioactivity in the presence of Upjohn 11, 100 shows considerable resemblance to those obtained with excess unlabelled estradiol. There are readily discernable differences between results using Upjohn 11, 100 and those found after preheating. The correlation however is considered

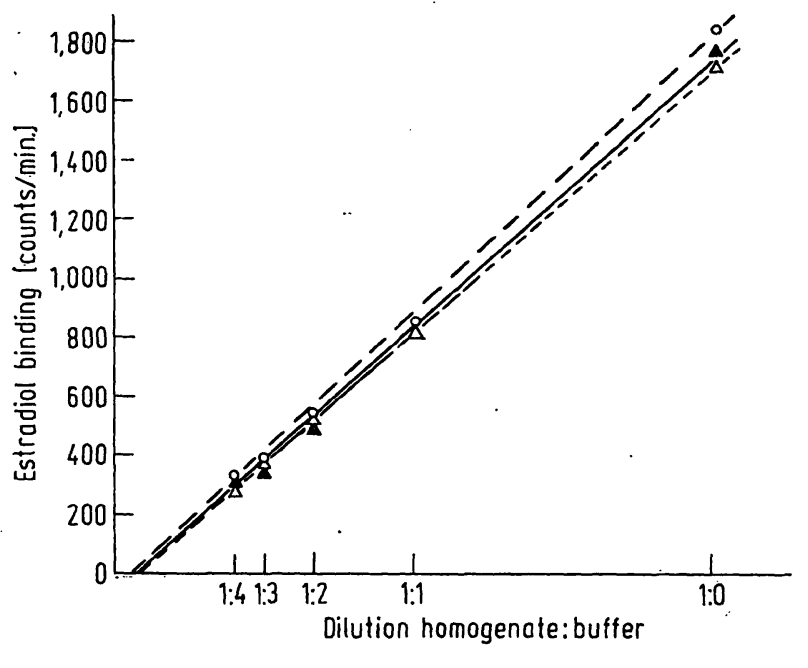

Fig. 4

Relationship of specirically bound ${ }^{3} \mathrm{H}$-estradiol and concentration of extract of mammary tumour. The different curves relate to the suppressibility of bound ${ }^{3} \mathrm{H}-\mathrm{estradiol}$ by urilabelled excess $(0-\ldots)$ or
by Upjohn $11,100(\Delta-\Delta)$ or by preheating $(\triangle-\Delta)$

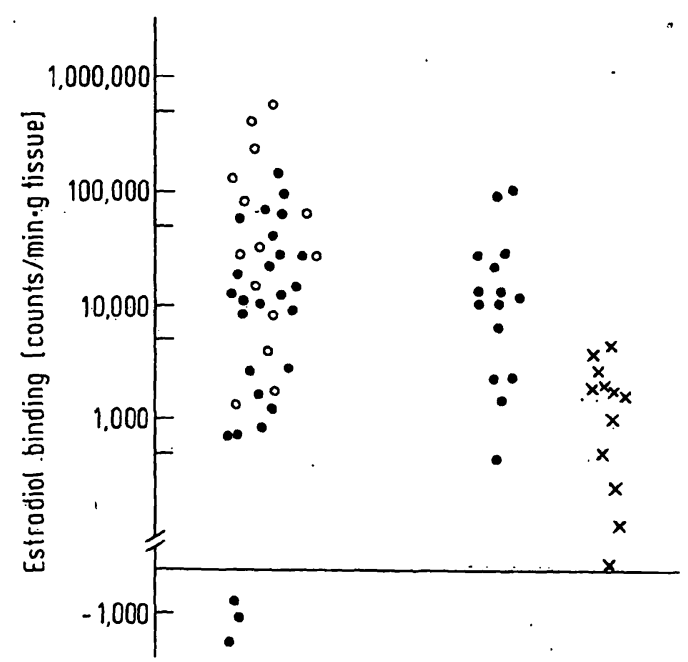

Fig. 5

Chart of estrogen binding capacities of primary mammary tumours ( $\bullet$ ) or metastases (o) (left and middle) and benign tumours ( $X$, right) as
calculated from the control experiments using Upjohn 11,100 


\section{Denken Sie jetzt an Datenerfassung und -verarbeiftenng 跑 llhrem Laboratorium}

\section{SILAB-System}

für Klinik

und Praxis:

Modular, organisch adaptierbar, ausbaufähig.

SILAB Identifikationssystem

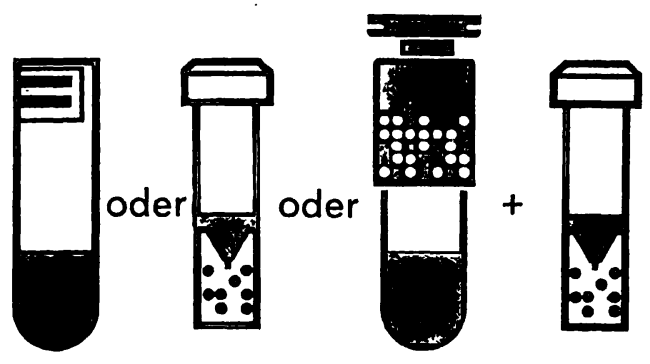

SILAB

Datenerfassungssystem

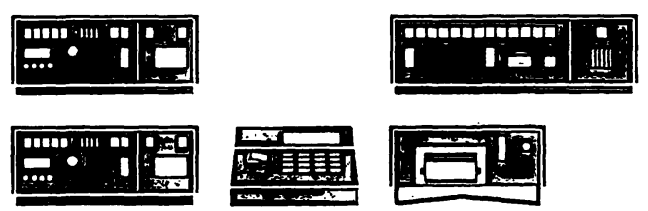

SILAB

Programmsystem

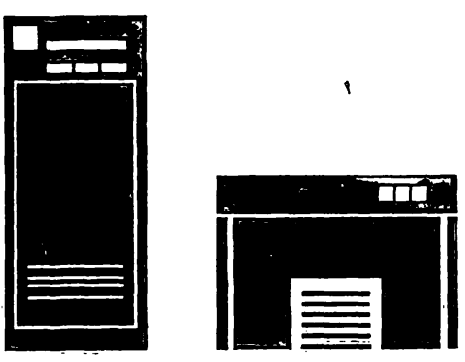

Direkte Probenkennzeichnung durch

Etikett oder maschinenlesbare Codierung. Unverwechselbare Zuordnung von Probengut und Meßwert zum Patienten. Manuelle oder automatische Probenverteilung.
Datenerfassung, Meßwertvorverarbeitung und Protokollierung am Arbeitsplatz. On-line-Anschluß der Analysengeräte oder Eingabe mit Tastaturen.

Datenprüfung und doppelte Datensicherung vor Übergabe des eindeutig gekennzeichneten Meßwertes an die Datenverarbeitungsanlage.
Echtzeit- oder Stapel-Auswertung der Daten, Umrechnung nach Eichkurven, Plausibilitätsprüfung.

Übersichtliche Ergebnislisten für Labor und Station.

Dokumentation und Statistik.

Sofortige automatische Fehlermeldung. Jederzeitige Information durch Dialoganfragen. 


\section{Verschiedene Milkrovolumina - in Sekunden abgeben

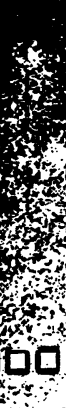

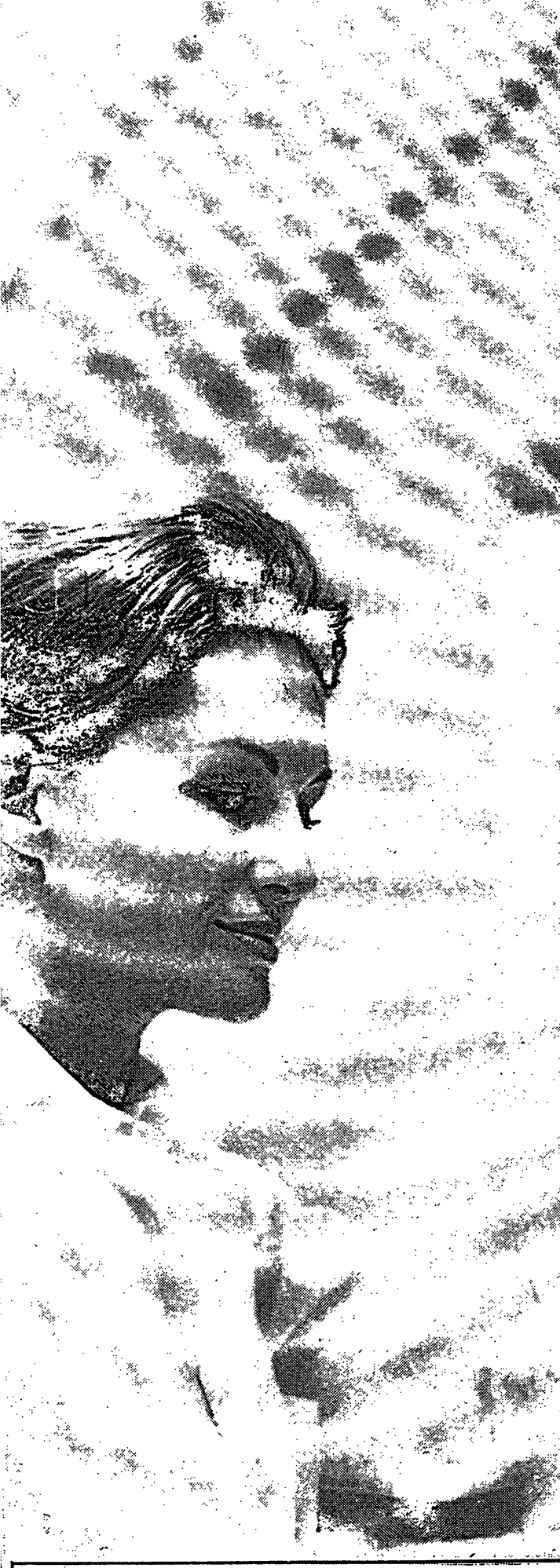

Autorisierter Händler für die BRD: GÜNTHER SCHRIDT

Hamburg - Frankfurt

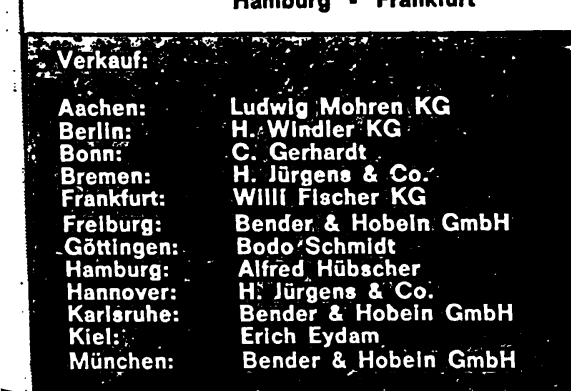

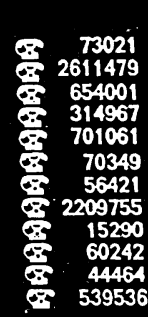

das kann der Hamilton-Aliquanter Stellen Sie die Anschlage auf die verschiedenen Volumina ejo verbinden Sie den Saugarm der Spritze mit einem, Vâkum und ziênen sie den holbender Spritze» zuruck das ist alles Dieispritze wirdiautomatisch

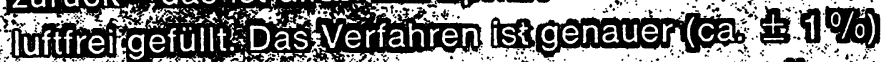

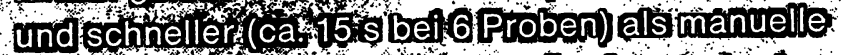
Pipettierung oder áutomatische Dosierung tuder Hämatologies bej Chlorid Bestimmungen, vielfachp Enzym:Bestimmungen oder Verdünungen. Genaueres lerfahren Ślemaus un seremKatalog, denwiti thrón auf anfrage gern zuschickenb. Bitteschrelben Sié an hamilton-Micromesure N.Vo Postfach 205, DeaHaag, Holland,

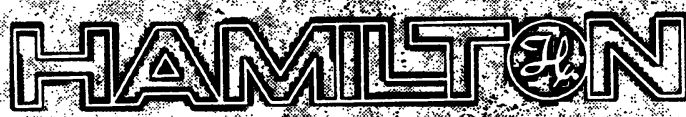


Tab. 3

Effect of unlabelled estradiol (excess), Upjohn 11, 100 or preheating on the binding of labelled estradiol by tumour homogenates (counts/min $\cdot g$ tissue)

\begin{tabular}{|c|c|c|c|c|c|}
\hline Patient No. & $\begin{array}{c}\text { with unlabelled } \\
\text { excess }\end{array}$ & $\begin{array}{c}\text { with Upjohn } \\
11,100\end{array}$ & after heating & $\begin{array}{l}\text { pre- or post- } \\
\text { menopausal }\end{array}$ & $\begin{array}{c}\text { primary tumours or } \\
\text { metastases }\end{array}$ \\
\hline 1 & 31,236 & 32,256 & 35,484 & post & met. \\
\hline 3 & 13,816 & 13,080 & 10,848 & post & prim. \\
\hline 4 & 1,200 & 696 & $-2,120$ & post & prim. \\
\hline 5 & 11,512 & 11,640 & 10,184 & pre & prim. \\
\hline 6 & 8,256 & 8,128 & 5,792 & pre & prim. \\
\hline 8 & 2,004 & 1,320 & -804 & post & met. \\
\hline 9 & 90,492 & 83,304 & 83,724 & post & met. \\
\hline 10 & 14,928 & 14,580 & 12,324 & post & met. \\
\hline 11 & 9,324 & 9,324 & 7,416 & post & met. \\
\hline 12 & 263,040 & 253,752 & 256,720 & post & met. \\
\hline 13 & 28,884 & 27,386 & 29,196 & post & prim. \\
\hline 14 & -184 & $-1,848$ & 1,328 & post & prim. \\
\hline 15 & 65,808 & 61,952 & 62,752 & pre & prim. \\
\hline 17 & 13,848 & 11,688 & - & post & prim. \\
\hline 18 & 2,216 & 1,680 & 1,928 & post & prim. \\
\hline 19 & -184 & -800 & $-1,616$ & post & prim. \\
\hline 20 & 72,240 & 68,832 & 68,696 & post & prim. \\
\hline 21 & 1,572 & -828 & $-5,976$ & post & prim. \\
\hline 22 & 20,208 & 18,800 & 15,728 & post & prim. \\
\hline 23 & 0 & $-1,074$ & $-2,388$ & pre & prim. \\
\hline 24 & 14,584 & 14,096 & 11,704 & post & prim. \\
\hline 25 & 31,928 & 29,864 & 29,288 & post & prim. \\
\hline 26 & 148,528 & 145,696 & 145,544 & post & prim. \\
\hline 27 & 11,964 & 9,096 & - & post & prim. \\
\hline 28 & 32,652 & 28,968 & 28,268 & post & met. \\
\hline 29 & 149,844 & 138,324 & 142,836 & post & met. \\
\hline 30 & 4,920 & 1,800 & 3,588 & post & met. \\
\hline 31 & 6,144 & 4,236 & 1,500 & post & met. \\
\hline 32 & 106,200 & 101,556 & 103,764 & post & prim. \\
\hline 33 & 70,440 & 65,568 & 61,260 & post & met. \\
\hline 34 & 53,916 & - & 59,292 & post & prim. \\
\hline 37 & 498,816 & 473,244 & 591,628 & post & met. \\
\hline 38 & 1,164 & 2,628 & 2,952 & post & prim. \\
\hline 39 & 648,864 & 602,640 & - & post & met. \\
\hline 40 & 34,152 & 29,724 & - & post & met. \\
\hline 41 & 2,784 & 2,856 & 996 & pre & prim. \\
\hline
\end{tabular}

as good since the results of both assays follow the same ranking order.

On preheating, some protein may undergo transformations resulting in an increased amount of unspecifically bound estradiol=17 $\beta$. This may explain the negative values (tables 2 and 3 , third column). Additional information is given in figure 5 which shows the distribution of binding capacities obtained by using Upjohn 11,100 as a control.

The points inserted left in this figure refer to the tumours listed in table 3. Additional data are given in the middle part of figure 5 . These data refer to predominantly postmenopausal histologically verified breast tumours. The area between $\pm 4,000$ and 8,000 counts $/ \mathrm{min} \cdot \mathrm{g}$ tissue, which is characterized by the relative absence of points, is considered arbitrarily as the separation of 'receptornegative', tumours from 'receptor-positive'. Thus, of the 56 malignant tumours described in figure 5, 39 contain estradiol receptors. Table 4 summarizes results obtained with benign breast disease. Of twelve cases, ten are considered to be 'receptor-negative' since they fall below the 4,000 counts/min $\cdot g$ tissue borderline. The data for the benign tumours, although limited to a small number of cases are in accordance with the data of JoHANsson et al (7). The benign cases have been inserted in figure 5 (right).

Tab. 4

Estrogen binding capacities in tissue samples of benign human breast disease. The assays were done using Upjohn 11, 100 in the control

\begin{tabular}{rlcl}
\hline Patient No. & Histology & $\begin{array}{c}\text { Estrogen binding } \\
\text { (counts/min } 8 \\
\text { tissue) }\end{array}$ & $\begin{array}{c}\text { pre- or post- } \\
\text { menopausal }\end{array}$ \\
\hline 1 & adenofibroma & 1880 & pre \\
2 & adenofibroma & 2640 & pre \\
3 & adenofibroma & 2016 & pre \\
4 & adenofibroma & 72 & pre \\
5 & fibrosis & 328 & pre \\
6 & mastopathia & 5616 & post \\
7 & mastopathia & 168 & pre \\
8 & mastopathia & 584 & pre \\
9 & fibrosis & 2216 & pre \\
10 & mastopathia & 4904 & pre \\
11 & mastopathia & 1720 & pre \\
12 & fibrosis & 1088 & pre \\
\hline
\end{tabular}


The coefficient of variation (C. V.) of the determinations of estrogen binding capacity was calculated to be $\pm 55 \%$ for the category of 'receptor negative' tumours $(<4,000$ counts/min $\cdot g$ tissue) and to be $\pm 11 \%$ for the category of tumours within the range of $8,000-20,000$ counts/ min. $g$ tissue. The large $C . V$. of the assays within the first group may explain a few negative results (see fig. 5). The binding of ${ }^{3} \mathrm{H}$-estradiol by the benign tumours showing less than 4,000 counts/min. $\mathrm{g}$ tissue was significantly suppressed by Upjohn 11,100 ( $t=4.5$, confidence level $95 \%$ ). The suppression by Upjohn 11,100 for the tumours within the category of $8,000-20,000$ counts/min.g tissue however, was distinctly more significant $(t=84.2$, confidence level $95 \%)$. Thus the tumours classified as 'receptor-negative' have a very low binding capacity which is statistically discernible from zero in spite of the large C. V. of the assay.

The above data on the significance of the suppression indicate that the differentiation of tumours possessing an estradiol binding capacity of less than 4,000 counts/ min. $\mathrm{g}$ tissue from those having an estradiol binding capacity higher than 8,000 counts/min $\cdot g$ tissue has some meaning. To test this differentiation, the group of benign tumours and the malignant tumours in the category $8,000-20,000$ counts $/ \mathrm{min} \cdot \mathrm{g}$ tissue, were investigated if their data follow different Gaussian distribution curves. The results are depicted in figure 6 . If the observed estrogen binding capacities were lying on one straight line, the above discrimination would not have a statistical meaning. From figure 6 it is evident that the group characterised by an estrogen binding capacity less than 4,000 counts/min - $g$ tissue (left line) is distinctly different from the group having higher estrogen binding capacity. It is interesting to note that two benign tumours considered from figure 5 as 'receptor-positive' belong to the group of malignant tumours with highly significant estrogen binding capacity (right line).

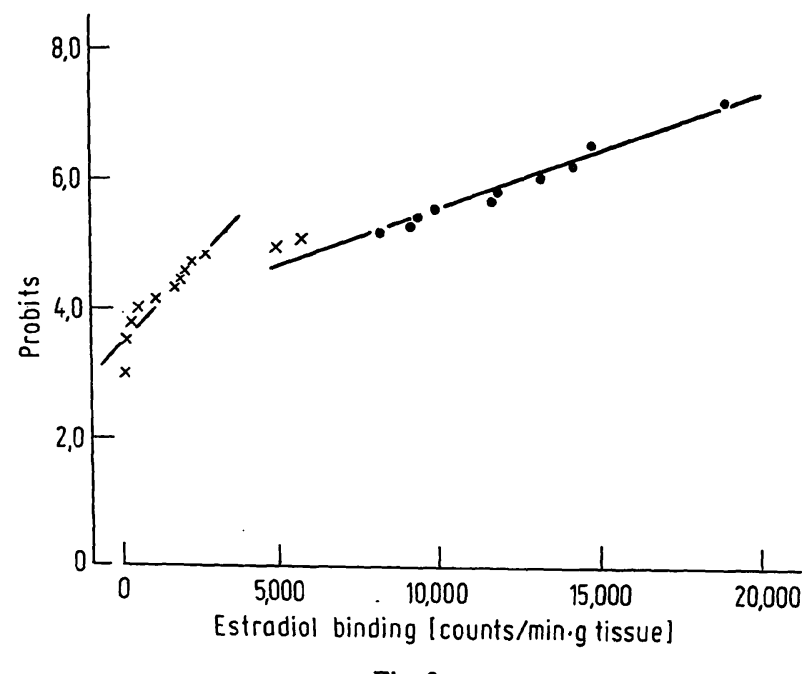

Fig. 6

Statistical evaluation of the observed estrogen binding capacities of the benign tumours ( $x$, shown in fig. 5 , right) and the malignant tumours belonging to the category of $8,000-20,000$ counts $/ \mathrm{min} \cdot \mathrm{g}$ tissue $(\bullet$, shown in fig. 5 , left)

\section{Discussion}

The usefullness of tissue slices for the assay of estradiol binding capacity of a tumour is limited since the time lapse between operation and the assay should not exceed 24 hours (7).

Another approach is the density gradient technique which is not practical as a routine. In addition the detection of non specific binding, by albumin may give problems since receptor bound estradiol may appear in the same region as albumin bound estradiol $(11,12)$. None of the above problems is encountered, if charcoal incubation or electrophoresis is used to discriminate against unspecifically bound estradiol. The first of these techniques is most simple to perform routinely but two points which need discussion are the specificity and the clinical aspects of the present method. The mechanisms of suppression of the amount of bound ${ }^{3} \mathrm{H}$-estradiol by Upjohn 11, 100 or excess unlabelled estradiol are different. JENSEN et al (1) were the first to demonstrate that Upjohn 11, 100 inhibits the uptake and incorporation of estradiol by target tissues like rat uterus or rat mammary tumour. Part of these findings were confirmed by TERENIUS (7) who also demonstrated that Upjohn 11, 100 inhibits the binding of estradiol in tissue slices taken from human mammary tumours. These studies involved a restricted number of tumours (seven). The results of the present study using homogenates give additional support that Upjohn 11, 100 inhibits estrogen binding by the receptor since Upjohn 11, 100 has an effect on estradiol binding comparable with preheating which denaturates the receptor $(11,12)$. Excess of unlabelled estradiol competes with the labelled for all binding sites which are saturable. Thus, sex hormone binding globulin (SBG) which is a constituent of normal serum even from post-menopausal women (13) may be estimated using the suppressibility of bound ${ }^{3} \mathrm{H}$-estradiol by excess of unlabelled estradiol. Since homogenates of tumours contain serum proteins, sex hormone binding globulin may be involved in the assay of the receptor in breast tumour homogenates. In this respect it should be noted that there is no evidence in the literature that Upjohn 11, 100 might interact with sex hormone binding globulin. Diethylstilboestrol which is simpler structurally, and, like Upjohn 11,100, also has a double ring system, does not bind sex hormone binding globulin (14). We have found that Upjohn 11, 100, unlike dihydrotestosterone, slightly reduces the binding of estradiol to plasma from pregnant women which contains high levels of sex hormone binding globulin (15). Preheating at $45-50^{\circ} \mathrm{C}$ for one hour partly destroys the capacity of sex hormone binding globulin to bind testosterone (13). From these points, it may be concluded that if sex hormone binding globulin interferes in the assays using preheating or Upjohn 11, 100 to discriminate for receptor bound estradiol, the interference will be minor. It was expected that with excess unlabelled estradiol a number of false positive cases should be found as compared to the other controls. Consideration of the data of table 3 
suggest that at least in the present study sex hormone binding globulin has not been present in sufficient amounts to be measured. It seems to us that for routine practice the technique presented in this paper can be restricted to the use of Upjohn 11, 100 as a competitor to the receptor and the preincubation at $45^{\circ} \mathrm{C}$ as an additional control. For a more refined study of any occurrence of sex hormone binding globulin the electrophoresis technique as developed by WAGNER (12) seems the method of choice. Further work will be devoted to this matter since we hope to improve the separation of the fractions.

The data of figure 4 show a linear relation between the amount of homogenate and the estradiol binding capacity. SANBORN et al (16) have studied the behaviour of the charcoal incubated and charcoal unincubated estrogen receptor complex in a sucrose gradient. Their results showed that a $10-15$ minutes incubation as used in the Korenman and Dukes technique was sufficient to bind excess estradiol. We have found that changing the incubation time from 5 to 25 minutes did not significantly effect the results of the assay which is in agreement with observations by TeRENIUS (17). The present method could therefore be considered to be quantitative but the clinical significance of quantitative interpretation of the result has still to be settled.

The results of the present study indicate that only some human breast tumours contain receptors, which agrees with earlier reports on in vivo binding of estradiol $(3,4)$, and that only certain tumours bind estradiol in vitro $(6,7,8,10)$. They are, however, in disagreement with these reports concerning the given percentages of tumours having estradiol binding capacity. JoHANSSON et al (8) and JENSEN et al (6) examined 51 and 31 tumours and found that approximately 40 and $50 \%$ possessed estrogen receptors, respectively. Terenrus (7) and Korenman and Dukes (10) studied a group of about 15 patients and found that $30 \%$ of the tumours bound estradiol. Concerning the disagreement with the reports which use homogenates $(6,10)$, it seems reasonable to assume that the higher percentage of positive findings in this study (about 70\%) is related to our homogenisation technique which gives a maximum of certainty that heat denaturation is avoided. During the preparation of this paper a report of FEHERTY et al (18) appeared describing an assay using low speed homogenisation with large intervals of cooling. It is interesting to note that these authors found estradiol binding in 37 out of 53 tumours. We feel that these data support our view that the choice of homogenisation technique is determined by the heat lability of the receptor protein. The differences of percentages with the reports using tumour tissue slices may be related to number of specimens used in the incubation and competition experiments which may be to low to average out the heterogeneity of the material. Another explanation would be that prior to the binding to the receptor some factor is involved determining the uptake of the hormone through the cell wall. This factor could influence the results in assays using tissue slices.

In 1967 JENSEN et al (1) suggested that knowledge about the presence of receptors in tumour tissue would make it possible to predict the response of human breast cancer to endocrine therapy. The reasoning was that tumours with estradiol binding receptors are estrogen dependent for their growth in analogy to estrogen responsive target tissues in animals. Since, roughly speaking, a third of the patients benefit from hormone therapy, a finding of $30 \%$ (7) of receptor positive tumours was considered by Terenius as a support for the above suggestion. The present study, however, reveals about $70 \%$, but it should be noted that part of these tumours have medium binding capacity. It may very well be that patients with tumours possessing high estrogen binding capacity would benefit from hormone therapy. This would imply that quantitative interpretation is necessary. One question to be solved is to which parameter (tissue weight or tissue DNA, or tissue protein, etc) it is clinically preferable to relate the estradiol binding capacity. Another problem is the effect of endogeneous estrogen levels on the measurements of specific estrogen binding capacity. In fact, any assay method published so far measures mainly latent estrogen binding capacity, since endogeneous estrogen is bound to the receptor so firmly that the rate of exchange with the labelled estrogen during incubation is low. For the present method an exchange of about $50 \%$ of endogeneously bound estrogens could be expected at the most (19). Johansson et al (8) and FEHERTY et al (18), using a shorter incubation time, consider that their data show the effect of endogeneous estrogens to be negligible. To gain more insight into this problem and into the relation between the presence of receptors and endocrine therapy, further studies involving estrogen assays in blood and tumours are now in progress. We feel that the present method, being simple and suitable for routine application, could be used in such studies.

\section{Acknowledgement}

We are indebted to Professor P. W. Jungblut and Dr. R. K. WaGNER (Max Planck Institute, Wilhelmshaven, Germany) and Dr. L. Terenius (University of Uppsala, Sweden) for stimulating discussions. We are grateful to the surgeons and pathologists and their staff in our Institute and the Onze Lieve Vrouve Gasthuis (Amsterdam) and of the Pathological Laboratory (Deventer) for preparation of tissue specimens. We are indebted to Dr. F. J. CLETON for reviewing the manuscript.

We thank Mr. A. KAMmeyer for valuable technical assistance. 


\section{References}

1. Jensen, E. V., Desombre, E. R. \& Jungblut, P. W. (1967), in Endogeneous Factors Affecting Horst Tumor Balance (Das, T. L. \& Wood, S., ed.) p. 15, Chicago University Press. - 2. JENSEn, E. V., Desombre, E. R., Hurst, D. J., Kanashrma, T. \& JunGBLUt, P. W. (1967), Arch. Anat. Micr. Morph. Exp. Suppl. 56, 547-569. - 3. Folca, P. J., Glascock, R. F. \& Irvine, W. T. (1961), Lancet II, 796-797. - 4. DEsPhande, N., JENSEN, E. V., Bulbrook, R. D., Berne, T. \& Ellis, F. (1967), Steroids 10, 219-232. - 5. James, V. H. T., JAMEs, F., BraunsBerg, H., Irvine, W. T., Carter, A. E. \& Grose, D. (1971), Studies on the uptake of oestrogens by human breast tumours in vivo. Memorial Found Workshop Conference, S. 20-39, Heinemann (London) Ed. - 6. Jensen, E. V., Block, G. E., SMith, S., Kyper, K. \& Desombre, E. R. (1971), National Cancer Institute. Monograph 34, 55-70. - 7. Terenius, L. (1971), Europ. J. Cancer 7, 57-64.
8. Johansson, H., Terenius, L. \& Thoren, L. (1970), Cancer Res. 30, 692-698. - 9. JungbuUt, P. W., Personal communication. 10. Korenman, S. G. \& Dukes, B. A. (1970), J. Clin. Endocrinol. Metab. 30, 639-645. - 11. WAGNER, R. (1971), in Schering Workshop on steroid. Hormone 'Receptors', S. 373, Pergamon Press. - 12. Wagner, R., To be published in Hoppe Seyler's Z. Physiol. Chem. - 13. Pearlman, W. H. \& Crept, O. (1967), J. Biol. Chem. 242, 182-189. - 14. Beaulreu, E. E., Personal communication. - 15. Clark, A. F., Calandra, R. S. \& Bird, C. E. (1971), Clin. Biochem. 4, 89-103. - 16. SAnBorn, B. M., RAs, B. \& KorenMaN, S. (1971), Biochemistry 10, 4955-4961. 17. Terenius, L., Personal communication. - 18. Feherty, P., Faner-Brown, G. \& Kellie, A. E. (1971), Brit. J. Cancet XXV, 697-710. - 19. Ellis, D. J. \& Ringold, H. J., The uterine estrogen receptor: a physico chemical study. To be published.

Dr. J.-P. Persijn

Antoni van Leeuwenhoek Huis 108 Sarphatistraat

Amsterdam/Niederlande 


\section{Ihr Ausguß wird ein armer Schlucker}

Nichts von den überschüssigen

Reagenzien, die sich beim Verdünnen mit Vollpipette und Meßkolben ergaben, fällt mehr für ihn ab.

Denn beim Brand-Dilutor brauchen Sie immer nur die Reagenzmenge, mit der Sie tatsächlich weiterarbeiten wollen. Dieser Dilutor spart aber nicht nur Reagenzien - also Geld sondern vor allem Zeit. Bei hervorragender Genauigkeit.

Mehr darüber auf der nächsten Seite
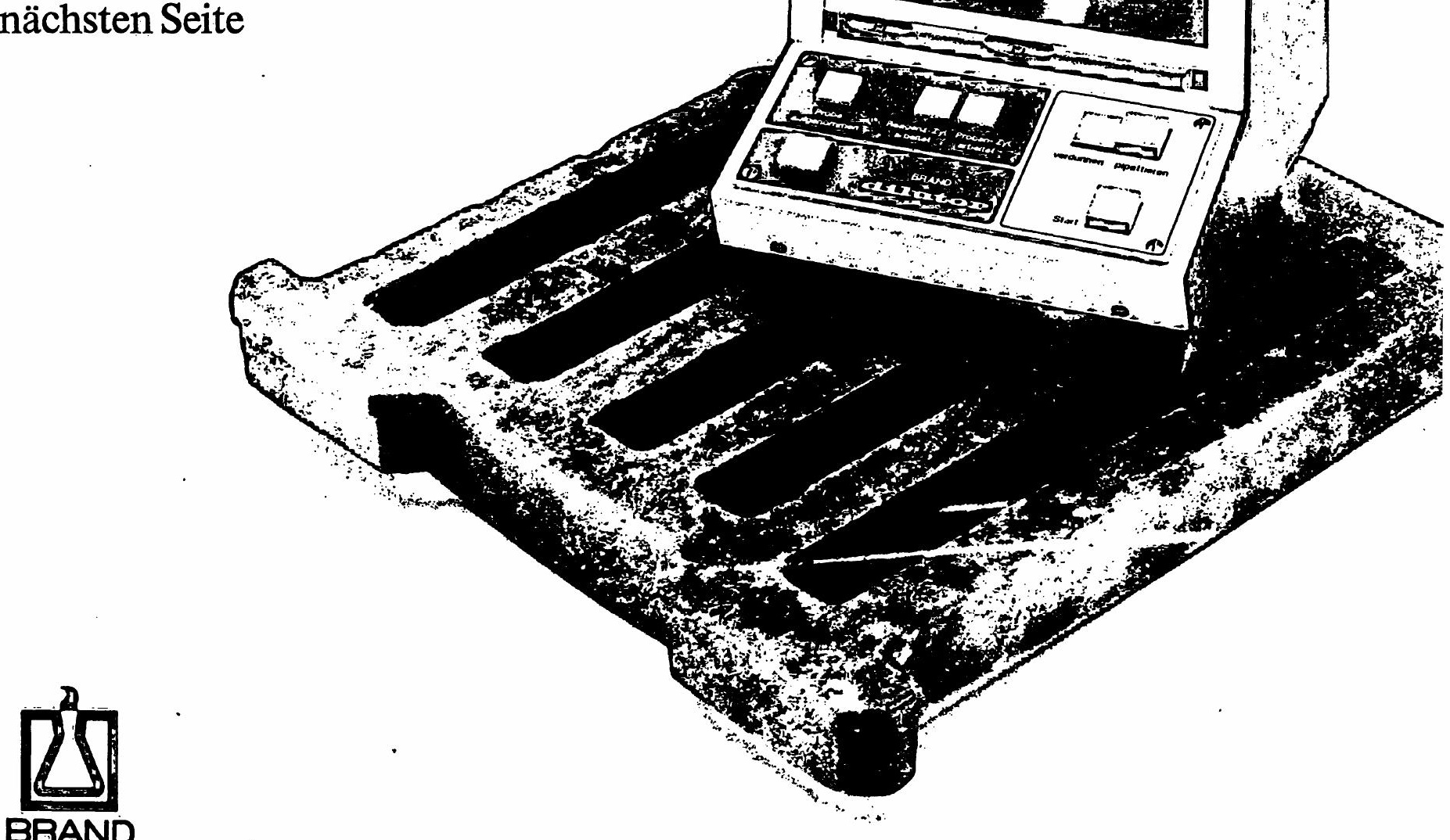

RUDOLF BRAND

LABORGERÄTE UND VAKUUMPUMPEN

698 WERTHEIM/MAIN · POSTFACH 310 


\section{Strömungswege, Kolben, Zylinder und Ventil bestehen ausschließlich aus Glas und PTFE \\ Digitale Volumen- einstellung Reagenzzylinder: $1 \mu-$ $5000 \mu$ \\ Probezylinder: $0,1 \mu l-$ $500 \mu$ oder: $1 \mu l-5000 \mu l$ \\ Zweite Wähltaste ermög- licht Verwendung als Dispenser}

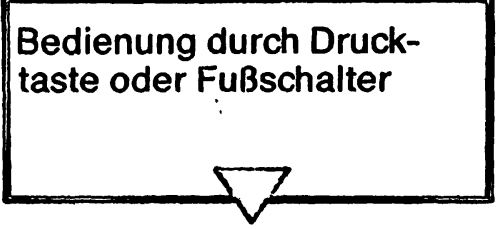

Erstes elektronisch gesteuertes Verdünnungsgerät

Schnelleinstellung in Mikroschritten von 0,1 bzw. $1 \mu$ (rechnerisch 25000000 verschiedene Mischungsverhältnisse möglich)

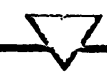

Nur zwei bewegte Teile an jedem Zylinder

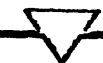

\section{BRAND-GEERÄTE}

WEIL DIE

RENTABILITÄT

ENTSCHEIDET

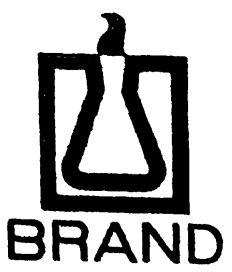

Universell einsetzbar durch ausgezeichnete chemische Resistenz und Anpassung an den Verwendungszweck

\section{Einfache und bequeme} Handhabung

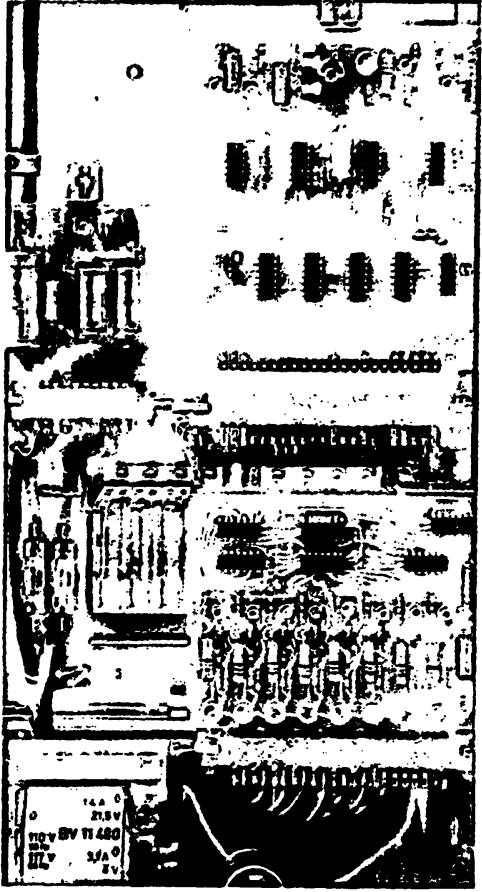

Extrem niedriger Einstellfehler auch bei geringen Probevolumina

\section{COUPON}

Außergewöhnlich gute Reproduzierbarkeit der Messergebnisse

Hier konnte Ihnen natürlich nur eine Obersicht über einige wìchtige Eigenschaften dieser Geräte gegeben werden. Wenn Sie aber diesen Abschnitt mit einer, notfalls unfrankierten, Postkarte an uns schicken, lassen wir Ihnen gerne weitere Informationen zukommen über:

\section{BRAND-DILUTOR}

BRAND Fabrik für Laborgerāte

@80 Wertheim-2 